\title{
THE NORMAN CONQUEST AND THE COMMON LAW: THE LEVELLERS AND THE ARGUMENT FROM GONTINUITY
}

\author{
R. B. SEABERG \\ State University of New York, Binghamton
}

Twenty-five years ago J. G. A. Pocock first argued that the Norman conquest was the rock upon which all arguments for the continuity of the common law finally came to wreck. Believe in the conquest qua conquest, and you could not believe that English law represented a continuous stream of unviolated custom or fail to see it as very much the offspring of Norman parentage. In the English revolution, the Levellers exemplified the logical necessity of Pocock's argument. Having seen the conquest for what it was, the group criticized the common law as none other than a Norman yoke and surrendered all appeals to history. By re-examining the Leveller use of history, this essay tests that proposition, turning it not upside down but on its side, and suggests an alternative conclusion both about the Levellers and the doctrine of continuity itself. $^{1}$

Several years before Pocock published his seminal work on The ancient constitution and the feudal law, Christopher Hill had divided protagonists of the civil war into two ideological groups: those who adhered to the common law theory of continuity, and those who did not. In a now famous essay on the myth of the Norman yoke, Hill noted that both groups shared an idealized view of the Anglo-Saxon legal world; but they parted company over the nature of William of Normandy's assumption of the English throne. Proponents of the theory of continuity, represented best by Sir Edward Coke, and later, the parliamentarians during the civil war, argued that whatever the assumption might have been it assuredly was not a conquest: William claimed the throne by ancient right and English laws and customs remained inviolate. Opponents, however, believed that William's assumption was achieved and maintained by force; and that Norman customs and institutions vitiated those of the simpler Anglo-Saxons. Though Hill and Pocock disagreed over certain particulars, they both placed the Levellers squarely among the opponents of continuity. One result of Pocock's argument was the severance of any real connexion

1 J. G. A. Pocock, The ancient constitution and the feudal law (N.Y.: W. W. Norton and Co., 1967 repub. of the 1957 edn), pp. 125-7, 232. In this essay, by the use of the word 'Levellers' I mean especially those men commonly regarded as the leaders of the group: Lilburne, in particular, the acknowledged centre of the group around whom a fraternity gathered as 'a company of Turbyes doe about a Frogge' (Bastwick, A just defense, 1645, E. 265.2, p. 17); Overton; Walwyn; and Wildman. 
between Coke and the Levellers. Their positions simply turned out to be mutually exclusive. ${ }^{2}$

Pocock also offered an appealing explanation of the apparent fundamental rift in Leveller thought - the reliance on and then rejection of the past. He found the answer in the nature of the conquest. When the Levellers came to regard the Norman conquest as the 'fatal breach' in the continuity of English law, they moved away from history toward natural rights theory as the groundwork for their political platform. The Leveller view of the conquest as the great divide in English history came from their reading of 'innocent historians' and chroniclers, whose writings provided a foil to the theory of Coke and the common lawyers. This conclusion came from Quentin Skinner in an article on 'History and Ideology in the Puritan Revolution'.

Once the Levellers had comprehended fully the historical lesson of the fatality of the conquest, the movement away from history - which, according to Skinner, gave peculiar shape to their thought and set them apart from both parliamentarians and royalists - resulted from an inescapable conclusion to a simple hypothesis: if there had been a conquest, which had broken the continuity of the law, and if after that conquest the law had been a yoke, then beyond feeble attempts at reviving a long dead Saxon paradise, the Levellers could not look to history and law for support and justification. Evidence supporting the first condition could be found in the works of those historians whom the Levellers read. And evidence for the second premise came from their own experience with contemporary law - which also seemed to dovetail with assertions by the chroniclers. In sum, Pocock believed that the syllogistic argument outlined above, formed out of historical and experiential knowledge, lay at the heart of the Leveller revolt against the existing structure of the common law and gave them a means to reject the 'historic constitution'.4

The reasoning, however, suffers from two fallacies which I believe ultimately prove fatal to it. First it depends on the mistaken assumption that the Levellers perceived all existing rule as an alien yoke dating back to I066: In point of fact, the leaders adopted a particular view of English law, based on their reading of historians and legists, which allowed them to turn the law against itself while always using the law as a yardstick by which to measure arbitrariness. In other words, their conception and use of the past - English history and law - did influence profoundly their political demands. Second, the denial of a conquest in order to affirm continuity does not necessarily mean

\footnotetext{
2 Christopher Hill, 'The myth of the Norman Yoke', Puritanism and revolution, (London: Secker and Warburg, I965 repub. of 1958), pp. 6o, 75-7. (Hill's essay was first published in Democracy and the labour movement: Essays in honour of Dona Torr, ed. John Savile, 1954.) Pocock, op. cit. p. 126. See also R. T. Vann, 'The free Anglo-Saxons: A historical myth', Journal of the History of Ideas, xIx, 2 (1958). Vann stated that the scholarship nurtured in the Inns of Court was the 'polar opposite' of the Leveller version of history (p. 268).

3 Pocock, op. cit. pp. 126-7. Quentin Skinner, 'History and ideology in the Puritan Revolution', Historical Journal, vin, 2 (1965), 153-4.

- Skinner, op. cit. pp. 153-4. Pocock, p. 127 . Hill had emphasized also the movement in Leveller thought, describing it as a passage from 'historical mythology to political philosophy' (p. 75).
} 
that the acceptance of a conquest denies continuity. In other words, the doctrine of continuity as understood and employed by the Levellers was no simple belief in unchanging law, but represented a more complex view of the rhythm basic to English history.

Interestingly, Pocock himself had pointed to the existence of a rich and intricate doctrine of continuity. In discussing the debate over the Petition of Right, a prelude to parliamentarian arguments in the opening years of the I64os, Pocock wrote: 'The men of 1628 could believe that they were not only repeating the solemn act of 1215 , but taking part in a recurrent drama of English history at least as old as the conquest.' J. W. Gough had drawn a similar conclusion in Fundamental law in English constitutional history. The purpose of the Petition of Right, he stated, 'was to secure a fresh definition and acknowledgment by the king of the ancient traditional and fundamental rights of Englishmen - to restore the constitution, which had become unbalanced, to its traditional poise'. That same belief, I maintain, animated the Levellers as well. They too sought a fresh definition of ancient liberties, and they found a convincing basis in English history as presented by the chroniclers. The historians whom the Levellers read, in particular Raphael Holinshed, Samuel Daniel, John Speed and William Martyn, pictured the past as a recurrent drama, a dialectic of promises (to rule by law, preserve ancient laws and respect ancient rights), renegations and demands for restoration. The Levellers not only adopted that view of the past, but saw themselves as linked inextricably to it. ${ }^{5}$

The four historians most frequently cited in Leveller pamphlets were in general agreement on the nature of the Norman conquest. To them, the conquest was just what the word implied, an event which produced, overall, a great alteration in English government and placed an 'intollerable yoke' on the English people. But they also concurred on the things which made the event an alteration and the alteration a yoke. It is these substantive points which figure most prominently in the Leveller understanding of the conquest and of English history. ${ }^{6}$

The 'yoke of thraldom', according to Holinshed, resulted from the fact that William had abrogated 'in maner all the ancient lawes used in times past' and 'made new, nothing so equall or easie to be kept'. Just what was it about the changes which made the laws less equal and more difficult 'to keep'; which in some manner amounted to an abrogation? The answer offered by both

${ }^{5}$ Pocock, p. 45. J.W. Gough, Fundamental law in English constitutional history (Oxford: Clarendon Press, 1955), p. $5^{8}$.

- Raphael Holinshed, The Chronicles of England, Scotland, and Ireland (London, I807, 6 vols.), $\mathrm{u}$, 9. For Daniel's concurrence, see 'Collection of the History of England', Complete works, ed. Alexander Grosart (New York: 1963, 5 vols.), Iv. I 33-4, 165-6, 17 1-2. For John Speed, see The Historie of Great Britaine (London, 1650 edn), p. $4^{28}$. 
Holinshed and Samuel Daniel concerned the introduction of new terms, forms of pleas, offices and courts. Specifically, they meant the innovations of exchequer and chancery, the translation of laws into the Norman language, quarterly terms at Westminster (which replaced gemotes, or monthly conventions in the hundred) and the appointment of central judges to replace men of the neighbourhoods. As a result, Daniel wrote, English laws came to be 'practized wholly in the Normans forme and language'?

The preceding paragraph contains almost all the essential elements of Leveller anti-Normanism. It omits only the enforced dependence on lawyers for pleading, but Daniel had much to say on that too. Both individually and in toto, the elements correspond to what is termed procedural law, or the administration of the law. The use and repetition of certain words in the histories, such as 'form' and 'practice', help to establish that correspondence. However, if the main points of Leveller anti-Normanism, historically based, referred to the administration of the law, then substantive law could still provide fertile ground for appeal and justification. This, in my opinion, exactly portrays the Leveller relation to the common law. The basic distinction between procedure and substance explains how the Levellers could both criticize English law as a creature of Norman force and call on it for support and defence. Perhaps the division might have been only implicit in the descriptions and judgements of Holinshed and Daniel; but John Speed articulated it quite explicitly. Writing of the laws collected by Edward the confessor, he noted that Edward had:

selected the best, and made of them one body certaine... to be the touch of his Commonwealth Pleas. and the squire by which he would have every right to be measured; being in a sort the fountaine of those, which at this day wee terme the Common Lawes, though the forms of pleading and process therein, were afterwards brought in by the Conquest. ${ }^{8}$

The division between 'fountaine' and 'process' is crucial to an understanding of the Leveller view of the conquest, its relation to common law and the doctrine of continuity. Investigation of a pamphlet by the prolific and at times ambiguous Leveller leader, John Lilburne, may serve to verify this point. I choose The Just Mans Justification because others have found it singularly important. T. C. Pease, in the first major study of the Levellers, remarked that that tract exemplified Lilburne's antagonism toward the common law and his adoption of the view that the law was a badge of slavery. Writing a half-century after Pease, Christopher Hill regarded the pamphlet as evidence that the Levellers believed the entire common law to be corrupt. ${ }^{9}$

Hill singled out a specific phrase from the tract - " the mainstreame of

7 Holinshed, p. 13. Daniel, pp. 1 $71^{-2}, 166-7$.

8 John Speed, p. 409. Law is commonly divided into the general categories of substantive and procedural. See, for example, T. F. T. Plucknett, A concise history of the common law (Boston: Little, Brown and Co., I956 edn), pp. $3^{80-2}$.

- T. C. Pease, The Leveller movement (Washington, D.C.: AHA, 1916), p. 132. Hill, op. cit. p. 76. 
the common law", - and added his own predicate, 'was corrupt'. The sentence thus completed represented his judgement on the Leveller relation to the law. Actually, the phrase formed part of a citation from Samuel Daniel, which read in its entirety: 'though there might bee some veynes issuing from former originalls, yet the mainstreame of our Common Law, with the practice thereof, flowed out of Normandy'. Hill was surely correct in his inference of corruption, but too facilely extended it to include the entire common law. Rather the phrase denoted common law procedure and was quite in keeping with the judgement by Speed. Lilburne, at least, drew that inference; for his criticism focused on the 'tedious, unknown and impossible to be understood common law practices in Westminster Hall'. The conqueror, he argued, robbed England of the traditional structure of the laws of Edward the confessor by setting up the dictates of his own will - "whose Norman rules, and practices to this day yet remains in the administration of the Common Law at Westminster'. Ambiguous and uncertain rules, entries in Latin, an enforced dependence on lawyers and on central pleading, these formed the elements of what Lilburne called an 'iron Norman yoke'. Even Magna Carta, restricted in application by a Norman administrative structure, suffered by comparison with the laws of the saintly Edward. ${ }^{10}$.

Lilburne urged contemporaries to annihilate the 'Norman innovation' and return the country to 'that part of the antient frame of government' antedating the conquest. The 'part' to which he referred was the adjudication of suits in the county or hundred in which they arose. His plaint supports my contention that Lilburne's rejection concerned procedural law. Furthermore, he believed that the return to local justice would help curtail the monopoly of lawyers, a 'wicked trade' which had grown proportionately to the growth in litigation after the conquest. The reforms Lilburne advocated included some sponsored by his former counsel, John Cook, in a tract titled $A$ Vindication of the Professors and the Profession of the Law. And, like Cook, Lilburne could maintain his reliance on English law while criticizing it, could view Magna Carta as a 'gallant law' and the 'Englishmans inheritance' while finding it less efficacious than the laws of Edward the confessor. The 'common law bryers' to which he referred, the 'punctillos and formalities' as he often styled them, as well as 'rules in the orracle of Judges brests' (i.e. arbitary practices and judgements), were all ills of process, language and administration. These were the ills which became the targets of Lilburne's reforms. ${ }^{11}$

Never one to divorce personal circumstances from political demand, Lilburne

${ }^{10}$ Hill, p. 76. Lilburne, The Just Mans 7ustification (2nd edn, 1647), E. 407 . 26, p. 14. (The First Part of this tract, pp. $\mathrm{I}^{-19}$, is the same as the original edition of the pamphlet and ends with the date 6 June 1646.) Daniel, iv, i66. Lilburne, The 7ust Mans 7ustification, pp. 14, 17.

11 Lilburne, The Just Mans Justification, p. 18. John Cook, A Vindication of the Professors and the Profession of the Law (London, 6 February $\mathrm{I}_{45}$ ), E. 320.17 , p. 66. Hill had included the relevant passages on practices and rules (pp. $76,80,8 \mathrm{I}$ ) and on the 'antient frame' (p. 8I), but he did not draw any conclusions from them. Instead he focused on the one phrase taken from Daniel. For Lilburne on Magna Carta, see Just Mans...p. 17; on punctillos, p. 5; on judges, pp. 12-13; on common law bryers, see The Freemans Freedome Vindicated (London, 19 June 1646), E. 341 1. 12, p. 6 
dwelled on the faults of the common law in The fust Mans fustification because the tract itself had been written to contest a suit at common law brought against him by Edward King, the presbyterian and former army colonel. Lilburne took the opportunity not just to argue why the case did not belong in a common law court but also to argue against his being tried by the rules of that law, which he felt no man fully and truly knew. Nevertheless, the argument for plainness in laws, for their translation into English so that a commoner might 'fully understand his own proceedings in the law', circumscribes the imputation of corruption. And that argument, together with the demand for other reforms, simply cannot be described accurately or meaningfully as the 'common law myth stood on its head, as Marx said he had stood Hegel'. ${ }^{2}$

What remained, then, of the common law after removal of Norman procedures and rules and the decisions of judges? To the modern reader, familiar with Henry Sumner Maine's judgement and with Maitland's teaching on the forms of action as the basis of the common law, apparently not much indeed. But that answer, overwhelmingly anachronistic, misses the point; for surely one must attempt to answer it in terms of what the Levellers felt remained and how that residue compared with contemporaries' statements about the common law. If the 'process' had been tainted, still the 'fountaine' remained - what Lilburne, following Coke, called the 'right reason of the rule', for one thing. How the law worked-unequally, harshly, slowlymight have afforded much subject for censure, but what the law proscribed and prescribed, substantive law, endured. Since, at basis, English law was synonymous with reason, and reason meant to do to another as one would be done to, then the fundamental injuction of the common law prescribed the biblical notion of fairness. Of course neither Lilburne's 'right reason' nor Coke's phrase on the law as the absolute perfection of reason offered much practical substance. But the descriptions do suggest a way of looking at the law and at various laws which went to the core of any legal system: laws were to regulate the behaviour of men in society, under the obligation, at least in England, of ensuring each his own. Working out from that core came the multitude of ancient customs and liberties, articles relating to meum and tuum, the coronation oaths of kings and statutes of the realm. Contemplating the heart of the matter, as Lilbure was wont to do, could exacerbate the division between procedure and substance. ${ }^{13}$

12 Lilburne, The Just Mans..., p. 5. On the commoner's understanding of the law, see Richard Overton, An Appeale from the Degenerate Representative Body. ., I 647 , E. 398.28. Pocock, p. 126.

13 Maine wrote: 'So great is the ascendancy of the Law of Actions in the infancy of Courts of Justice, that substantive law has at first the look of being gradually secreted in the interstices of procedure' (Early law and custom, p. $3^{89}$ ). See also Maitland, The forms of action at common law. For Lilburne's use of 'right reason', see The fust Mans...p. 18. The phrase, 'right reason of the rule', had been used by Coke in his gth Report, xIv. There are numerous examples of the equation of English law with reason and the law of God by sixteenth- and seventeenth-century legal writers: St Germain, Doctor and student; Sharington $v$. Strotton, 7 and 8 Eliz. I Plowden, $303 \mathrm{ff}$, the judge declaring 'For there is nothing in our law contrary to nature or reason or the law of God, but our law is agreeable to them all'; James Morice, one of those who argued against the ex officio oath, wrote that English law consisted of the prudent precepts of reason (Reading on 
One must also ask whether and to what degree Lilburne's vision was shared by his colleagues. Richard Overton's pamphlet, A Remonstrance of many Thousand Citizens, provides an appropriate checkpoint, since historians have found that tract as telling an example of the Leveller rejection of history as any by Lilburne. Pocock believed it exemplified the 'language of political rationalism':

yee were chosen to worke our deliverance and to Estate us in naturall and just liberties agreeable to reason and common equitie, for whatever our Forefathers were; or whatever they did or suffered, or were forced to yeeld unto; we are men of the present age, and ought to be absolutely free from all kindes of exorbitancies, molestations or Arbitrary power. ${ }^{14}$

These were strong words and, to Pocock, clear evidence that the Levellers 'could not appeal to Law, but to natural right and reason'. Yet, upon closer scrutiny, the passage is remarkable for its inclusion of generally accepted notions and concepts taken-for-granted. Few of Overton's contemporaries would quarrel with the statement that men ought to be free of arbitrary power and excessive intrusions. Indeed, it would have been truly remarkable to find terms such as reason, equity, just liberty, etc. missing from Leveller pamphlets! ${ }^{15}$

The passage from $A$ Remonstrance reflects a vital aspect of English legal tradition. Many legal authorities stated explicitly - and none contradicted the principle that laws, usages and customs not agreeable to the eternal and

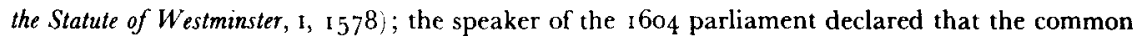
law was 'grounded or drawn from the law of God, the Law of Reason, and the Law of Nature' (7.July 1604, Commons Journal, I, 254a); in The Justice of the Peace, etc., 1746 edn Justice Michael Dalton cited Fortescue's De Laudibus, asserting that 'the common laws of this realm of England, receiving principally their grounds from the laws of God and Nature (which law of nature, as it pertaineth to man) is also called the law of reason'; Sir Henry Finch stated that laws against the law of reason were not properly laws at all (Law, or a discourse thereof, 1627, pp. 75-6); in 1628 Dudley Digges argued that 'the Laws of England are grounded on Reason, more ancient then Books' (Rushworth, Historical collections, I, 527); Sir John Doderidge noted that the common law was 'often styled in our books common reason' (The English lawyer, 1631, p. 62); the conception was summed up by Coke in the Second Part of the Institutes, p. I 79 - the common law was the absolute perfection of reason. To William Walwyn and the other Leveller leaders, reason meant to do unto others as one would be done to, a clear equation of the law of God with reason. Walwyn's understanding was not a peculiar one. Thomas Elyot, in The Book named the Governor, had defined reason as a counsel which bids a man 'to do the same thing to another' that he would have done to himself (Book in, iii, 164). In An Appeale from the Degenerate Representative Body (1647), Overton declared that reason was the fountain of all precedents. This declaration is not evidence of his political rationalism, but rather his view, in keeping with the general opinion, that the concept of giving one of his own, fairness, remained the heart of the law. (The Levellers were fond of using the phrase, 'the letter kills, but the spirit giveth life'.) Further, the statement did not imply either an aversion to precedent or a negation of its importance. Overton juxtaposed two users of precedents: those who preferred 'formalities, formes and figures' and those who looked to the 'substance, life and spirit of all just precedents and Lawes'. He rebuked only the former. The juxtaposition should be seen as yet another version of the distinction between the 'life' of the law and its administration, or substance and practice (pp. 157, 158, 159).

14 Richard Overton, 'A Remonstrance of Many Thousand Citizens', 27 July I646, Tracts on Liberty, ed. William Haller, (New York: Columbia University Press, I933-4, 3 vols.), iI, 4.

15 Pocock, p. 127. 
natural law were not the law of the land. The common law embodied principles of justice which gave to each of his own; that is, the rights and liberties of the subject, ordained by the will of God, were to be maintained by the law. Given that, Overton did not need to, nor did he, reject the law. In fact, on basis the pamphlet was a sustained argument for the rule of law. It began reminding the reader of the 'ancient established constitution' and ended reminding the House of Commons of their own censure of King Charles - that his reign had been 'one continued act of the breach of the law'. Overton's reminder meant to recall parliament to the task of upholding the law. Certainly it left room for criticism, and Overton followed the leads of Lilburne and William Walwyn. ${ }^{16}$

Like his colleagues, Overton directed his criticism against legal administration. He censured the litigiousness and vexation introduced by the Normans; their methods for ending controversies which had replaced hundred courts; and their erection of a 'trade of Judges and Lawyers to sell Justice'. He called Magna Carta a 'beggarly thing', but that paraphrase of remarks by Walwyn concerned in the main the charter's placement within a Norman procedural system. Therefore, he did not find it inconsistent to follow that criticism with another tract (written some weeks later) which called Lilburne's position 'agreeable to Magna Carta' and the charter itself 'that little remainder of light'.17

The next major effort of the Levellers, Liberty Vindicated against Slavery, very likely the work of Overton as well, was a veritable panegyric on Magna Carta. The cause of England's maladies, the tract observed, should be attributed to the casual observance or non-observance of the great charter. A November I 646 pamphlet, Vox Plebis, which claimed authorship of Liberty and contains more evidence of Overton's hand, praised Magna Carta as a 'brazen wall and impregnable Bulwark, that defends the Common Liberty... from ... Arbitrary Power'. ${ }^{18}$ Perhaps the nature of Leveller criticism of Magna Carta, and by

16 On those authorities, see footnote i 3. F. D. Wormuth has stated that: "In the i 5 th century, it became usual to speak of English law as bearing some relation to the law of nature and reason, a characterization borrowed from Roman law' (Origins of modern constitutionalism, New York: Harper and Row, 1949, p. 207). See also Gough, Fundamental law, pp. 18-19, 23, 40. Overton, 'A Remonstrance', pp. 3, 5.

17 Overton, 'A Remonstrance', pp. 19, 15, г2. An Alarum to the House of Lords, 31, July 1646. E. 346.8 , p. 6

18 Liberty Vindicated Against Slavery, 21 Augsust, 1646, E. 351.2, pp. 19-20. Vox Plebis, or, The Peoples Out-cry Against Oppression, Injustice and Tyranny, I9 November, 1646, E. 362. 20, p. 9 (misnumbered, should be p. 7). Most historians (e.g. D. B. Robertson, The religious foundations of Leveller democracy, Joseph Frank, The Levellers, Don Wolfe, Milton in the Puritan Revolution and Pauline Gregg, Free-born John) have assumed Lilburne to be the author of Liberty Vindicated Against Slavery. However, several points militate against such an assumption and suggest Overton as the author. Lilburne had been confined to the Tower in August under heavy security. The Lords had set down in detail the precautions to be taken to ensure that he would not be able to write and certainly not to publish anything. Not even his wife was allowed access to him until September. (Lords Journal, vin, 491; Anatomy of the Lords Tyranny, 9 November 1646, E. 362.6, pp. 16-1 7.) It took some time for the severe restrictions to be relaxed. In Londons Liberty in Chains Discovered, p. $6 \mathrm{I}$, Lilburne specifically disclaimed authorship. Since the argument of the pamphlet did show 
extension, of the common law, is best summed up by William Walwyn. His words describe perfectly the division between substance and practice that, in turn, describes the Leveller view of English law. They are, therefore, worth quoting in full:

For howsoever men in these days make bold to trample Magna Charta under their feet, making sport at the many absurd prerogative and superstitious things therein contained; it is to be noted, that those things are but as a French garb or cloathing, which the Conqueror and his successors, by main strength, forced our forefathers to put on: but yet, as an Englishman is to be known from a Frenchman amongst a thousand, though he labor to fashion himself as the most Frenchified Gallant; so are our true English liberties contained in Magna Charta, as easie to be differenced from amidst that superstitious and in some measure tyrannical heap cast upon them, and which that worthy Parliament in the third year of the late King, culled out to purpose, and reduced into that excellent Law ... the Petition of Right. ${ }^{19}$

It may be Walwyn was gently rebuking himself, remembering his own description of the charter as a 'messe of pottage' several years before. If so, he could at least take some comfort in the fact that he had never trampled Magna Carta, but only urged that the liberties it contained were mixed in a thick soup with anti-libertarian elements. The metaphor had changed, from food to clothing, but spoke the same. It presents a problem to those historians who have claimed that Walwyn found neither Magna Carta nor the common law to be a guarantor of liberties. ${ }^{20}$

In Liberty Vindicated against Slavery, and in many other tracts, the Levellers laid England's difficulties at the door of non-compliance with Magna Carta. Overton explicity equated the March, or 'Large', Petition of 1647 with the

a familiarity with earlier Leveller writings and with Lilburne's ideas, criticisms and experiences, the tract could very well have been authored by Overton. He was able to write from Newgate prison during this period, since a broadside appeared under his name on 9 September. Overton was well acquainted with Coke's Institutes, the major source for most of the argument, and he knew as well the historical works cited in the tract, particularly Daniel's History of England. The thesis of Liberty was continued in a November pamphlet, Vox Plebis. The author/s of that tract referred to Liberty as 'our former treatise'. Unfortunately, the authorship of Vox Plebis has not been agreed upon. Pease and Robertson suggest Henry Marten. Pauline Gregg selects Overton, with possible assistance from Marten. Wolfe (Milton in the Puritan Revolution, NY: Thomas Nelson, 1941, p. 472) claims that 'much of this tract was probably written by Overton'. In this case, I agree with Gregg and Wolfe. Certain internal evidence suggests Overton as the author, in particular the historical arguments (cf. Englands Miserie and Remedie and $A$ Remonstrance); the specific references to Livy's Decades and to republics in history. These had all appeared in earlier tracts written by Overton. It is very possible, however, that he was aided by Marten, and perhaps Lilburne, especially if Marten was helping to get them published. Nonetheless, I take Overton to be the guiding hand behind both Liberty Vindicated Against Slavery and Vox Plebis. Liberly, p. 6. Vox Plebis, pp. 4, 6, 9 (7).

19 William Walwyn, Juries Justified (London, ${ }^{6} 6_{51}$ ), E. 618. 9, p. 5 .

${ }^{20}$ For the 'messe of pottage' phrase, see Walwyn, Englands Lamentable Slaverie (London, 1645), E. 304 - 18 , p. 4 . 
great charter, charging that the House's order to burn the petition by common hangman was a command to torch the charter of English liberties. In Vox Plebis, he put Magna Carta at the centre of an historical continuum, which he called the 'perpetual establishment of liberty'. This position, reflected in other Leveller pamphlets as well, recalls 1628 . During debate on the Petition of Right, Sir Benjamin Rudyerd uttered the words: 'I shall be very glad to see that old, decrepit Law Magna Charta which hath been kept so long, and lien bedridden, as it were, I shall be glad to see it walk abroad again with new vigour and lustre'. If that was grist for Pocock's mill, it is meal for mine as well. The Levellers too had assumed familiar roles in the drama of English history. ${ }^{21}$

The doctrine of continuity as expressed by John Pym - again during debate on the Petition of Right - characterized as well Leveller thinking:

There are plain footsteps in those laws in the government of the Saxons. They were of that vigour and force to overlive the Conquest; nay, to give bounds and limits to the Conqueror... It is true they have been often broken, (but) they have been often confirmed by the charters of Kings and Acts of Parliaments. But the Petition of Subjects, upon which those charters and Acts were founded, were ever Petitions of Right, demanding their ancient and due liberties, not suing for any new. ${ }^{22}$

To Pym, the burden of continuity rested not on its unbrokenness, but on the recurrence of popular demands for ancient rights and the confirmation of them by kings and parliaments. The fact that there had been interruptions in the enjoyment of rights, that there had been suspensions and losses of liberties, did not, indeed could not, negate that traditional nature of the laws and liberties whose observance Englishmen demanded so many times. If anything, the language of the demands fostered and transmitted a conviction as to their traditional character. The coronation oaths of kings, along with various promises to observe and confirm, gave validity and strength to the concept of continuity. For continuity, in a fundamental sense, was established as much by demand and belief as by fact. The Levellers believed it no crime 'to lay claim unto the Fundamental Lawes and Liberties' of England. Such had been the constant appeal of Englishmen 'throughout all succession of Governments and Changes'. ${ }^{23}$

By what right, then, did the Levellers lay claim to lost liberties? The answer is simple. It did not involve an inability to appeal to law, as Pocock postulated, but rather incorporated the same appeal as their fathers had made: a claim to lost liberties by the same right as that claimed by the English at Runnymede, during the reigns of Henry III, Edward I and Edward III and by members of parliament at the deposition of Richard II. The Levellers appealed to the

21 For Overton's equation of the Large Petition and Magna Carta, see 'An Appeale from the Degenerate Representative Body the Commons', Leveller manifestoes, ed. D. M. Wolfe (N.Y.: Thomas Nelson, 1944), pp. I 70-1. Vox Plebis, p. 6. Rudyerd quoted in Faith Thompson, Magna Carta, its role in the making of the English constitution 1300-1629 (Minn.: University of Minnesota Press, 1948), p. 86.

22 Pym quoted in Rushworth, Historical collections (London: D. Browne, 172 I-2), 1, 596.

23 Anon., The fundamental lawes and liberties of England, $9 \mathrm{July,}, 6_{53}, \mathrm{E} .705 \cdot 5, \mathrm{p} .2$. 
substance of English law and to the dynamic of oaths, broken promises and recurrent demands against the forces of innovation and usurpation; that is, against the 'exorbitancies' of arbitrary power.

I have tried to show in the first part of this essay that the Levellers could believe in a kind of continuity to English history because they did not view the Norman conquest as the fatal breach in English tradition. The innovations introduced by William concerned the administration of the law, and throughout subsequent ages, Englishmen attempted to re-establish a pre-conquest legal structure. Clearly, some of those changes meant the loss of liberties; but they were liberties whose restoration could be demanded on the grounds of tradition. Then too, the Levellers believed that several key institutions, both substantive and administrative in character, had survived the conquest. Trial by jury was one such. Placing it within what he called the 'kalendar of Englishmens fundamental liberties', Lilburne noted that all the conquests, Roman, Saxon, Danish and Norman, had failed to blot out that most important entry from the table of liberties. ${ }^{24}$

In arguing the antiquity and continuity of the jury system, Lilburne (and then Walwyn) adopted Coke's version as opposed to that propounded by the chroniclers - who judged trial by jury a Norman custom. Lilburne also accepted Coke's view that William had held several parliaments during his reign - in apparent contradiction to the statements of the chroniclers and his own testimony in earlier tracts (as well as that of his associates). One could, of course, perceive both arguments as creatures of circumstance. That is, one might judge Lilburne's defence of juries in the light of his acquittal for treason by a jury in 1649 and his demand for a jury trial when faced with the second treason charge in 1653 . Likewise, the 1649 statements on the continuity of parliaments through the conquest (i.e., even the conqueror held free and successive parliaments) followed Pride's purge, the sitting of a rump parliament, the creation of a council of state, the execution of Charles and the imprisonments of Lilburne and other Leveller leaders. More precisely, they countermanded arguments by Hugh Peter who, while defending the rump and council of state, contended that parliament was but a creature of the conquest and branded it with the epithet 'Norman'. Anyone reading a selection of Leveller pamphlets could not argue with the observation that they were written out of the personal experiences of the authors, dictated in some measure by circumstance. But to dismiss them as circumstantial and pragmatic is to forfeit a vital key to understanding Leveller thought. ${ }^{25}$

24 Lieut. Col. John Lilburnes plea in law, 2nd edn, 2 July 1653 (Houghton Library, Harvard University, ${ }^{*}$ EC 65. L62 $\left.75.65 \mathrm{pb}\right)$, p. 8.

${ }^{25}$ For Coke's version of the antiquity of juries, see his Third Reports, vII. On the chronicle accounts of the institution of the jury, see Holinshed, II, I3 and Daniel, Iv, I6g. On Lilburne's adoption of Coke's view on the continuity of parliaments (his quoting of the Institutes), see The Legall Fundamentall Liberties of the People of England (London, 8 June, I649), E. 560. 14, p. 44. The argument between Hugh Peter and John Lilburne was chronicled in: A Discourse betwixt L. C. John Lilburn... and Mr Hugh Peter, London, 1649), E. 556.26, passim and Robert Massey; The Examination and Correction of...the Discourse, B. L. 1473 . bb. 12, passim. 
In fact, the arguments were quite telling. The concept of a 'kalendar' of liberties which existed through history and weathered a series of conquests robbed the Norman conquest of its uniqueness. The conception was not of Lilburne's own devising, but could be traced to the writings of those same historians and chroniclers whom Quentin Skinner felt were responsible for the Leveller acceptance of the conquest as a conquest. Holinshed, for example, maintained that the laws of Edward the confessor-admired by allrepresented a restoration of laws promulgated by king Edgar and then abrogated by the Danes - 'for a time'. The fact that those same laws then went unobserved by William (and subsequent kings) and were the subject of manifold demands for confirmation and restoration also served to wrest from the Norman conquest its fatality and hence its reputation as the great breach, and placed it instead within the give-and-take of English history. ${ }^{26}$

The chronicle accounts helped in still another way to put the conquest in perspective, especially the dynamic of the English past. According to Pocock, let us remember, the fact of a conquest put the lie to any belief in continuity: if William had been an absolute king, ruling by a jus conquestus, then regardless of whether he maintained English laws or introduced French substitutes, what had been done occurred by his will. Therefore, the common lawyers and Coke had to maintain that William claimed the throne by right of ancient law and then vindicated the claim by right of battle. William's victory thus brought him no title to change the laws of England; and rather than doing so, he confirmed them. While they disagreed over the presence of force, however, the historians concurred on a significant point - William's claim reflected no such ancient law. On that they represented a profound difference with the common law view. ${ }^{27}$

Samuel Daniel claimed that William's right was 'of his own making',though he would not style him a 'conqueror'. Yet, the fact that the right was self-made did not mean that William ruled by a jus conquestus. Neither Harold's promises nor those of Edward (assuming he had made any), Daniel explained, could 'alter the course of a right succession'. Further a successor was not the heir of the king but the kingdom, and any testament 'against the law and custome of the Kindome' was invalid. One faces, then, a somewhat paradoxical conclusion: William gained the throne by will and not by right; but such a gain was invalid on the grounds of English tradition. What, exactly, had William gained? How could he have gained the crown by will and yet not ruled by will? 28 $^{2}$

The answer lay - albeit dormant - in Pocock's own words. Since the concept of an ancient contitution rested ultimately on the idea of custom, he argued, its value existed ' as a purely negative argument,' namely that law was above will. If negative to Pocock, however, that argument went to the heart of medieval tradition. And as expressed by Bracton, it explains the paradox: where will ruled in place of law, there was no king. Of course Bracton's words
26 Holinshed, I, $747^{-8 .}$
27 Pocock, p. 53 .
28 Daniel, IV, I53, 149. 
were written long after the conquest, but they describe very persuasively why William bothered to claim the throne by ancient right after throttling Harold - he wanted to be a legitimate king and not a tyrant! Therefore, he had to submit to the coronation oath, promising to 'governe the people in justice' and to 'ordain righteous lawes and keepe the same'. Subsequently, when he began to govern by Norman administrative customs, and translated the laws into French, the people petitioned him to remember the coronation oath and the laws of Edward the confessor. To that petition William assented in the form of a charter, thus confirming what he had promised twice before. ${ }^{29}$

Both Daniel and Holinshed agreed that the oaths and confirmations were deceptions. William never fulfilled them and perhaps never intended to. But the important point, as William Prynne realized in The Soveraigne Power of Parliaments - aside from the example of duplicity, which enjoined a constant vigil for liberties and demands for restoration - was and remained the fact that William had submitted to the coronation oath and had confirmed English laws and liberties. Prynne acknowledged that several medieval chroniclers had omitted mention of that submission; but he had decided on the veracity of the accounts in Roger de Hoveden and then Daniel, supported as they were by Foxe's Acts and Monuments and Lambarde's Archaion. ${ }^{30}$

The Levellers incorporated Pyrnne's realization into their own understanding of the conquest. In Vox Plebis, Overton asserted that William had entered by force, but upon petition of the lords and commons, had confirmed the laws of Edward. Lilburne fashioned the coronation oath into a central part of the repertoire of Leveller arguments: direct references and allusions to it abound in the corpus of Leveller tracts. Even John Wildman, who charged at the opening of the Putney debates that the chronicles were without credit, spent much time in those same debates arguing for the fundamental importance of the coronation oath - historically conceived as a crux of the 'old foundations of our government'. ${ }^{31}$ In his I 648 pamphlet, $A$ Reply to the House of Commons, Wildman noted: 'For the Conqueror, though the sword made his entrance, yet he could not make himself fast, til he came to an Agreement with the People, and was swore by them to maintain their laws.' ${ }^{32}$ Lilburne shared his

29 Pocock, p. 5 1. Holinshed, II, 2 I.

30 Holinshed, II, 16. Daniel, Iv, I65-6. Prynne, The Soveraign Power of Parliaments and Kingdomes (London, I643), part 1 , pp. $5^{1-2}$.

31 Vox Plebis, p. 6. Lilburne's use of the coronation oath argument figures prominently in: Innocency and Truth Justified ( ${ }_{1} 6{ }_{4} 6$ ); The Peoples Prerogative and Priviledges (1648);A Whip for the Present House of Lords (1648). See also Wildman, The Lawes Subversion (1648). For Wildman's disparagement of the chronicles during the Putney debates, see Puritanism and liberty, ed. A. S. P. Woodhouse (London: Dent, $195^{\circ}$ reprint edn), pp. 65-6; and his reliance on the argument from the oath, pp. 102-4. The Leveller understanding and use of the coronation oath as embodying the doctrine of consent was based on the traditional maxim, 'Quod omnes tangit ab omnibus debet approbari'. In the oath, that maxim was signified by the phrase, 'quas vulgus elegerit'. These phrases appear directly in several tracts and in the record of the Putney debates. I believe the Leveller understanding was based on Prynne's analysis in the Soveraign Power of Parliaments, part 1, pp. 47, $49,51-2$.

${ }^{32} A$ Reply to the House of Commons (London, 4 November, 1648), E. 470.6 , pp. 6-7. 
colleague's appraisal, a fact, I surmise, which made all the easier his acceptance of Coke's version of the continuity of parliaments. In The Legall Fundamental Liberties of 1649 , he wrote that William:

Three severall times took his oath after his being owned for king, to maintain their lawes and liberties, as not being able, nor judging his Conquest so good, just, and secure a Plea to hold his new-got Crown by, as an after mutuall compact with the people, or their representatives over whom he was to rule. ${ }^{33}$

Perhaps the most interesting points in the citations from the two Levellers concern the equation of coronation oath and compact and the description of the oath as an 'Agreement with the People'. There is ample reason to assume that Lilburne and Wildman consciously were identifying the oath as compact with their own 'Agreement of the People'. If that is true, then the Leveller 'Agreement' was historical and existed within the recurrent drama of the past. It was meant to function as had the coronation oath, although it represented an extensive fleshing out of the few words of the royal promise, and thus was suitable for the investiture in power of a new government.

Clearly, several important differences separated Coke and the Levellers. Coke viewed William's assumption of the throne as the exercise of his right of ancient law and believed that William proceeded to uphold English laws. The Levellers, however, saw that assumption as a forcible entry followed by an imposition of Norman customs. Still, the imposition primarily affected the administration of the law - only a 'partial disinheritance', as Henry Parker had characterized the conquest. And more important, one crucial point of agreement passed between the common lawyer and the quasi-legists: William had taken the coronation oath and had confirmed English laws and liberties. Force, Henry Parker observed, could not frustrate the tenor of the law. That was exactly the meaning of Daniel's assertion that any testament against law was invalid. And William chose to submit to the law. That submission, exemplified in the oath, formed one pole of the doctrine of continuity. ${ }^{34}$

The fact that William neither complied with his submission nor fulfilled his promises gave vent to continuing demands for reconfirmation and restoration, demands which endured throughout the reigns of subsequent kings and indeed into the seventeenth century. This, as Pym had made clear, formed the other pole of the concept of continuity. Together, the two poles embraced a rich and dynamic doctrine, almost protean in character; for it proved capable of providing at least modest sleeping quarters to such apparently strange bedfellows as Coke, William Prynne, and the Leveller leaders. In fact, Prynne had given eloquent expression to the tradition, with all its interruptions, in that jumble of history and law entitled The Soveraigne Power of Parliaments. Leveller pamphlets show that the leaders were as thoroughly familiar with that work as they were with another published by authority of parliament, Coke's Institutes.

${ }^{33}$ Lilburne, The Legall Fundamental Liberties, p. 44.

${ }^{34}$ Henry Parker, Observations upon some of his Majesties Late Answers and Expresses (London, I $_{42}$ ), E. 153.62, p. 3 . 


\section{I I}

There is indeed something compelling in Sir Herbert Butterfield's comparison of the English and French revolutions. The English, he argued, appealed to 'historic rights' and 'ancient custom' as if they were living things. That appeal saved them 'from the pressure of a fossilized antiquity.' The French in 1789 , on the other hand, 'ended in fact by cursing their middle ages and repudiating their past. French liberty springs from a revolt against history and tradition'. He concluded that the English made peace with their middle ages 'by misconstruing them.' The Levellers were as much guilty of misconstruction as their contemporaries. Therefore, the appeal to the past, to liberties historically enjoyed, remained efficacious. ${ }^{\mathbf{3 5}}$

Interestingly, the English have always relished making comparisons between themselves and the French, and certainly not to the benefit of the latter. One need only recall Fortescue's $D e$ Laudibus. Lilburne too made a comparison, wholly in favour of England, between the English subject and the French peasant slave. The crucial distinction was the benefit of the rule of law enjoyed by the subject as opposed to the arbitary power which governed the life of the slave. And Walwyn characterized the arbitrary and usurpatory elements in English law as a 'French garb'.36

One can take the comparisons as evidence of the noted insularity of the English and establish how that insularity inhibited the growth of historical criticism, or, when breached, aided the development of true historicity. This has been done by Pocock and, more recently, by Donald Kelley. But Butterfield had already acknowledged the presence and force of historical misconstruction. And if one looks at the comparisons in another light, they help to restore a needed perspective, certainly on how the Levellers viewed themselves. In his comparison between the English and French, Walwyn made peace with the English middle ages and by doing so with the common law. But the final words on the Leveller understanding of the common law must come from the acknowledged leader, John Lilburne. Six years after the time that he supposedly rejected that law, Lilburne described the common law as:

The birth-right and inheritance of the People of England; yea of the meanest as well as of the richest: And although the Law of England be not so good in every particular, especially in the administrative part of $i t$, as I could wish it were; yet till I see a better, I (for my part) will make much of that which we have, as the principal Earthly preserver and safeguard of my life, liberty and property. ${ }^{32}$

In sum this essay has been a plea to rethink the nature of Leveller political theory. It rests on their approbation of English law and its continuity, their appeal, in other words, to their own conception of the ancient constitution. And

${ }^{35}$ Herbert Butterfield, The Englishman and his history (Cambridge: Cambridge University Press, г944), pp. 6, 7 .

${ }^{36}$ John Lilburne, A Declaration to the Free-Born People (London, 1654); but especially The Legall Fundamental Liberties. Walwyn, Juries Justified (see n. 19).

37 Lilburne, A Remonstrance of Lieut. Col. John Lilburne (London, 1652), E. 652.5, p. 5 . 
it has sought to do that by understanding the Leveller attitude toward the common law and its continuity in light of the conquest by the Normans. The debate, I hope, will not be side-tracked by the view that the Levellers are best understood as early democrats of a peculiarly modern character or precursors of the French revolutionaries who repudiated their past, or even solely by the recriminations of their contemporaries who admittedly wanted to discredit them. The Levellers clearly were none of these things; they were rather individuals who saw themselves as heirs to the English tradition and who believed they had assumed familiar roles in the recurrent drama of English history. While they may have hurled many rebukes against elements of that past, the Levellers never repudiated it.

Let me close with a parting salvo. It comes from an anonymous Leveller pamphlet of 1653 :

The People are the Beginning, Medium, and End of, and through the whole Frame of Englands Lawes and Government thus founded and laid by Our Fathers, whose heirs we are, and which we must claim as our chiefest Birth-right and Inheritance: All is prepared and ready to our hands, our Lawes made, our Government founded: Our work is not now to tear up these foundations, to innovate or introduce any new Constitution or Frame of Government, but to maintain defend and preserve the old Freedom from the encroachments and usurpations of Kings, Lords, and Priests. ${ }^{38}$

There has been much recent concern for millenarianism and the radical eschatology of early modern Christian groups. But this passage recalls one to another fundamental element of the Judaeo-Christian tradition: the command to remember the days that are past. Even Overton's admonition to the men of 'the present age', seen in this light, enhances rather than repudiates that injunction. It is tradition, misconstruction notwithstanding, that the Levellers proclaimed.

${ }^{38}$ The Fundamental Lawes and Liberties of England, p. 2. 